\title{
'Known and Feeling Sorrows': Disabled Knowledge and King Lear
}

\begin{abstract}
This essay argues that King Lear presents a version of disability determined not by bodily authenticity but by bodily knowledge. By staging multiple forms and experiences of disability, the play defies the drive to authenticate and control non-standard bodies that flourished in early modern England. King Lear's insistence on embodied knowledge both recognizes the unique perspective afforded to disability and resists disability exceptionalism through its attention to populations made vulnerable to impairment. King Lear specifically dramatizes the way disabled knowledge extended to precarious populations by granting Edgar disabled knowledge even though his disability is fraudulent.
\end{abstract}

King Lear is a play about disability. By this I mean that King Lear is a play invested in understanding what disability is, showing how it operates, and expressing its lived experience. It does not only engage with disability as an instrument for understanding other concepts or conditions. It does not treat disability exclusively as a metaphor or an allusion, pointing away from itself and to something else. King Lear does not make disabled characters backdrops for able-bodied characters, nor does it use disabled characters merely to frame the stakes of its action. Instead, King Lear fills the stage with disabled bodies: mutilated bodies, marginalized bodies, unstable bodies, unwieldy bodies, bodies in pain, bodies at the edge of death. King Lear centres disability, making its disabled characters and their experience its primary dramatic preoccupation.

Much of King Lear's dramatic action focuses on what may be termed 'disabled knowledge'. Its characters speak to their sensations of impairment, their awareness of their rejection and difference, and their strategies for negotiating their social and built environments. Seemingly paradoxically, however, one of the characters who demonstrates disabled knowledge in the play is Edgar, a counterfeiter of

Lindsey Row-Heyveld (lirh@luther.edu) is an associate professor in Luther College's English department. 
madness rather than a genuine madman. How do we reconcile the play's prioritization of disability's embodied knowledge with its inclusion - and seeming validation - of the fraudulent experience of disability? I argue that King Lear subverts the drive to authenticate and control disability in early modern England by presenting a version of disability determined not by bodily authenticity but by bodily knowledge. In particular, King Lear's disabled knowledge encompasses the relationship between disability and poverty. The result is an expansive understanding of disability that recognizes the value of Edgar's experience and extends its embodied knowledge to the audience of the play.

Disability in early modern England invited epistemological crisis. Who was disabled? How could you be sure? Policing the line between the 'deserving' and 'undeserving' poor became more urgent and fraught throughout the early modern period, and disability defined that line. Reformation-era social changes transferred charity from the domain of the church and its parishioners to the government - turning almsgiving into social aid — and physical impairment became the primary qualification for receiving compensation. ${ }^{1}$ So for both regular citizens and the magistrates tasked with enacting these policies, disability demanded scrutiny that tested both the beholder's ability to determine the truth and the disabled person's ability to prove the authenticity of their impairment.

Anxiety about identifying disability sparked a rich theatrical tradition on the early modern English stage. More than forty plays from this period stage ablebodied characters faking disability. Although diverse in their genres, styles, presentations, situations, and themes, these plays all dramatize the difficulty of correctly interpreting disability. Onstage audiences are presented with fake disability, and the play's dramatic tension hinges on whether or not they will correctly identify the ruse. Wise audience members are skeptical and are typically rewarded for their suspicion of disability; foolish audience members are gullible and punished for their charity. Although the stage tradition of counterfeit disability is not monolithic, its instruction to offstage audiences remains consistent. The tradition teaches suspicion about disability and warns against individual almsgiving. ${ }^{2}$

Shakespeare's King Lear stands as both the most visible representative of the counterfeit-disability stage tradition and its greatest outlier. It features the spectacular counterfeiting of Edgar, heir to the duke of Gloucester, who disguises himself as Poor Tom, a 'Bedlam beggar' wandering the countryside pleading for alms. In many ways, Edgar's performance of madness fulfills the conventions of the counterfeit-disability trope. It shows the counterfeiter putting on his disguise and concludes with his unmasking; it takes up the central themes of the tradition (metatheatricality, identity, charity); and it places the dramatic focus 
of the counterfeiting scenes on the reception of onstage audiences, rather than the performance of disability itself. At the same time that King Lear complies with many of the conventions of this tradition, however, it also breaks with it in a fundamental way. King Lear undercuts the epistemological questions raised by disability in early modern England by widening the category of disability to recognize the way nonstandard bodies relate to economic crisis rather than epistemological crisis. (Disabled supplicants were by definition impoverished, a fact that the counterfeit-disability tradition elides but King Lear asserts.) As a result, King Lear paradoxically disregards Edgar's fraudulence and focuses instead on his disability. In doing so, the play also breaks with the counterfeit-disability tradition by supporting uncritical, if not unlimited, charity.

Disabled knowledge in King Lear is not mystical insight conferred through the semi-supernatural state of being disabled or the purifying suffering of the body. ${ }^{3}$ Nor is it knowledge that exists only to be transferred to able-bodied characters/audiences; disabled knowledge is not for the edification of the able-bodied. Rather, King Lear's disabled characters embody knowledge in a way that defies the insistence on authentication stressed by early modern legal authorities and the counterfeit-disability stage tradition. Edgar says that he possesses 'good pity' only through 'the art of known and feeling sorrows' (4.6.217-20). ${ }^{4}$ All of the characters in King Lear with disabled knowledge achieve it by 'the art of known and feeling sorrows', the practice of physical deprivation and limitation. That practice supersedes the authenticity of their impairment.

King Lear stages disability defined by knowledge that results from the experience and perspective of stigmatized, nonnormative bodies. Tobin Siebers establishes that disability is recognizable in Shakespeare (and fiction generally) when characters 'embody the knowledge of what it means to be a disabled person'. Siebers states, 'Disability is a body of knowledge - a collection of skills, qualities, properties, and characteristics, among other things - both driven by the built environment and transformed by the variety and features of bodies. ${ }^{6}$ I assert that King Lear not only enacts this version of disability but advocates for it. At the same time, the disabled knowledge of King Lear reformulates understandings of those bodies. Merri Lisa Johnson and Robert McRuer theorize disabled knowledge as 'cripistemology' and explore the ways in which it includes 'disability at the places where bodily edges and categorical distinctions blur or dissolve (where the disabled body as literal referent is, if not dematerialized, then differently materialized). ${ }^{7}$ When it comes to disability, interpretation often takes the form of diagnosis, attempting to uncover the 'defect' of an individual body, just as early modern authorities sought to authenticate and control unwieldy bodies 
physically and interpretatively. ${ }^{8}$ Understanding disability as a body of knowledge rather than a specific type of body resists the authoritarian logic of these classificatory systems.

King Lear defies early modern constructions of disability as a condition or criteria and recasts it as a body of knowledge by allowing disability to speak with multiple voices. Its disabled characters acquire their embodied knowledge differently. Gloucester's knowledge of disability comes suddenly and dramatically when he is blinded. Lear's knowledge settles in slowly with his gradually developing madness. The Fool knows disability from the very start. Early modern fools even witty ones - existed within the context of disability, and Lear's fool in particular voices his familiarity with disability throughout the play. He knows what it means to be silenced even though you speak, to be destitute even when kept by a king, and to live (or die) at the mercy of others' amusement or contempt. ${ }^{9}$ Edgar initially knows disability only from the outside, the 'proof and precedent' of the wandering madmen he plans to imitate. But his counterfeiting literally exposes him to the reality of disability. His costume consists of near nakedness, leaving him aching in the cold, and he lacerates his 'numbed and mortified bare arms' with sharp objects (2.2.186). His painful disguise blurs the lines between real and feigned disability, and his experience of destitution as Poor Tom further erases that boundary. Weak, exhausted, hungry, cold, in pain, and confused, Edgar undergoes what Susan Wendell describes as the 'the process of encountering the able-bodied world' when he experiences 'the world as structured for people who have no weaknesses' ${ }^{10}$ In concert, the play's disabled individuals build a body of knowledge that is collective but not coherent.

Although sometimes dissonant and disconnected, the multiple voices of disability in King Lear point to an understanding of disability that allows for multiple 'ways of telling' (to borrow Johnson's phrase). ${ }^{11}$ The voices that speak of disability in King Lear all speak differently. The Fool speaks wittily, angrily, and responsively, his speech usually prompted by others. As Tom o' Bedlam, Edgar speaks quotationally, repetitively. As himself, Edgar often speaks only to himself. After his blinding, Gloucester regularly keeps his sentences short, letting his silences speak to his exhaustion and pain. Lear's speech is circular, confused, stuttering, and often language-less: 'Fie, fie, fie! Pah pah!' (4.6.125); 'Now, now, now, now' (168); 'Then kill, kill, kill, kill, kill, kill!' (183); 'Sa, sa, sa, sa' (199); 'No, no, no, no' (5.3.8); 'Howl, howl, howl, howl' (255); 'Never, never, never, never, never' (3.7.307); and 'O, o, o, o' (5.3.308). ${ }^{12}$ Including multiple ways of speaking disability, as well as multiple disabled speakers, resists the demands of coherence and consistency required by early modern authorities in their assessment of disabled 
supplicants, revealing King Lear pushing back against the restrictive performance mode and paradigm demanded of disability.

When Lear, the Fool, and Edgar all endure the storm, for instance, their various perspectives speak to the specificity of their disabled positions. The Fool, who has the most experience with disability, wants to find shelter; his embodied knowledge prompts him to fixate on physical necessity. The Fool also recognizes the way that the weather doesn't discriminate based on disability ('Here's a night pities neither wise men nor fools' [3.2.12-3]) and can, in fact, create disability ('This cold night will turn us all to fools and madmen' [3.4.77]). Lear begins by claiming that he cannot feel the storm because his personal betrayal causes greater pain than any inflicted by mere weather. But as David K. Anderson notes, the material reality of his situation becomes inescapable the longer Lear stands in the driving rain. He cannot personify or metaphorize the storm; his aching, freezing body and his increasingly distracted mind ground him in the material world, keeping him from abstracting himself or his situation even as he loses hold of himself and his situation. ${ }^{13}$ Similarly, Edgar initially tries to draw meaning from the suffering he sees in the storm and attempts to justify Lear's anguish. ${ }^{14}$ But the physical ordeal of being naked, cold, wet, and without shelter eventually exposes the flimsiness of Edgar's moralizing. Although varied in their expression and experience, the Fool, Lear, and Edgar all acquire irreproducible knowledge of vulnerability and the ways that material reality can obliterate abstraction.

The characters in King Lear also enact embodied knowledge's destabilizing power. In particular, disabled knowledge unsettles dominant understandings of the nonstandard body. This destabilizing of accepted notions of disability comports with the project of cripistemology outlined by Johnson and McRuer. They articulate the "importance of challenging subjects who confidently "know" about "disability", as though it could be a thoroughly comprehended object of knowledge.' ${ }^{15}$ As I argue above, King Lear exposes the narrowness of early modern constructions of disability by including intermittent disability (Lear), verbally skillful disability (the Fool), and even fraudulent disability (Edgar) in the scope of its concern.

Disabled knowledge in King Lear destabilizes institutions, especially those systems and beliefs that undergirded systematic control of disability in early modern England. In attending to disabled knowledge today, Carrie Sandahl exhorts contemporary disability theorists to learn from the most marginalized members of the disabled community since 'what they know, how they know and why it matters is most threatening to the status quo. ${ }^{16}$ The destabilizing disability knowledge possessed by the people at the ragged edges of society of whom Sandahl speaks is not 
limited to the twenty-first century. In King Lear, the characters come to radical realizations at the moments of their greatest vulnerability. Freezing in the storm and spiraling into madness, Lear realizes that his suffering is not unique:

Poor naked wretches, wheresoe'er you are,

That bide the pelting of this pitiless storm,

How shall your houseless heads and unfed sides,

Your looped and windowed raggedness, defend you

From seasons such as these? O, I have ta'en

Too little care of this. Take physic, pomp,

Expose thyself to feel what wretches feel,

That thou mayst shake the superflux to them

And show the heavens more just.

Knowledge, here, is feeling, specifically feeling the systematic suffering of the disabled poor and the poor disabled. Previously sheltered from the lives of his abject subjects, Lear, thanks to his embodied knowledge of disability, now recognizes for the first time the suffering of others and his own complicity in that suffering. Further, his recognition identifies a solution to the problem of suffering: the distribution of charity to the poor by rich people like himself. Gloucester comes to similar knowledge after the onset of his disability. Bleeding and blinded on the road to Dover, he puts a bag of gold in the hands of Poor Tom and tells him,

Here, take this purse, thou whom the heaven's plagues

Have humbled to all strokes. That I am wretched

Makes thee the happier. Heavens deal so still!

Let the superfluous and lust-dieted man

That slaves your ordinance, that will not see

Because he does not feel, feel your power quickly:

So distribution should undo excess

And each man have enough.

Gloucester's speech clearly mirrors Lear's prayer. He too now appreciates the needs of the specifically disabled poor because of his embodied knowledge. Gloucester, like Lear, realizes his complicity in the distress of the disabled poor. And Gloucester also identifies indiscriminate charity as the solution to suffering. In direct opposition to early modern reforms that institutionalized the mistrust of disability under the auspices of regulating charity, Gloucester imagines the redistribution of wealth, no longer hindered by suspicion, as the means of restoring justice. ${ }^{17}$ 
Disability in King Lear is also defined by the relational nature of its knowledge. The characters gain knowledge of disability not only through their own physical sensations and how their bodies interact with the built and social environment but also through the way their embodiment engages with other bodies in all their rich variety. When the newly blinded Gloucester encounters his son Edgar disguised as Tom o' Bedlam, for instance, his knowledge of disability shapes his response. Although the old man who accompanies Gloucester identifies Tom primarily as mad, calling him 'poor mad Tom' and a 'Madman, and a beggar too', Gloucester alters this assessment, saying, 'He has some reason, else he could not beg' (4.1.29; 32-3). Gloucester focuses on Tom's nakedness, rather than his madness. He calls him 'naked fellow' twice and also 'this naked soul', and he goes out of his way to arrange for him to be clothed $(4.1 .42,54,46)$. In this encounter, Gloucester's disabled knowledge guides him. He orients himself towards the material sufferings of disabled bodies and invests in providing for disabled people rather than authenticating their disability.

King Lear reveals that disabled knowledge is built in relationship. When Lear and Gloucester happen upon each other in 4.6, their encounter is the first time either has met the other since the onset of their impairments. Their specific disabilities at first keep them from recognizing the other person: Lear's madness cannot make sense of Gloucester's bloody, bandaged eyes, and he mistakes his old friend for Cupid; Gloucester's blindness cannot make sense of Lear's madness, and he is unsure whether he can identify the voice of his king. While their conditions initially create confusion and disassociation in relation to one another, both Lear and Gloucester develop greater disabled knowledge when they are together. The two men never fully sort out their perceptions, but putting their distorted senses together allows them to come to new understanding. Commenting on the way 'this world goes', Gloucester says, 'I see it feelingly'. To which Lear responds, 'What, art mad? A man may see how this world goes with no eyes. Look with thine ears. See how yon justice rails upon yon simple thief. Hark in thine ear: change places and handy-dandy, which is the justice, which is the thief?' (4.6.144-50). Their confused senses - seeing hands and looking ears — perceive the injustice of the world accurately and with physical immediacy, even when they cannot fully make sense of anything else.

Still embodying his Tom o' Bedlam persona, Edgar watches Lear and Gloucester's encounter, and his proximity engenders new disabled knowledge in him. $\mathrm{He}$ describes his reactions to watching their meeting in the language of impairment: a 'side-piercing sight' and his 'heart breaks at it' $(4.6 .85,138)$. Johnson and McRuer assert that 'The production of knowledge about disability comes not only from 
being disabled but from being with and near disability, thinking through disabled sensations and situations, whether yours or your friend's.' ${ }^{18}$ Edgar articulates the relational origins of disabled knowledge at the end of the scene, when Gloucester again asks him who he is. This time Edgar responds, 'A most poor man, made tame to fortune's blows / Who, by the art of known and feeling sorrows, / Am pregnant to good pity' (4.6.217-19). Edgar fakes disability, but the 'known and feeling sorrows' that he both experiences and shares in give him genuine embodied knowledge so that he carries compassion like a pregnancy, a condition that offers new life at a perilous price.

King Lear's depiction of embodied knowledge both recognizes the unique perspective afforded to disability and resists disability exceptionalism through its attention to the way some populations are made vulnerable to disability. In King Lear, disabled knowledge isn't limited to a particular type of body but, instead, embodied by those on the social and economic margins, people Jasbir A. Puar identifies as 'precarious populations.' ${ }^{19}$ Puar describes 'injury and bodily exclusion that are endemic rather than epidemic or exceptional' in the twentieth- and twenty-first centuries, including within the category of what she terms 'debility' both individuals with shared ailments and populations identified as expendable. Precarious populations incorporate groups of people whose injury, exhaustion, or suffering is regarded as a 'natural consequence' of labouring. ${ }^{20}$ King Lear's depictions of precarious populations reveal a continuity between the sixteenthand early-seventeenth centuries, where capitalism roared into strength and the impulse to scrutinize and control nonnormative bodies flourished, and the latecapitalist neoliberal surveillance state Puar investigates. The play's vision of disability, then, privileges disabled knowledge without assuming epistemic privilege for or restricting epistemic privilege to the disabled body.

King Lear dramatizes the way disabled knowledge extended to precarious populations in this era through several means. First, it consistently pairs disability and poverty. While the simultaneity of disability and poverty might seem to be self-evident, it is not and especially was not evident in an era that suspected disabled beggars of being wealthy layabouts in disguise. But when characters in King Lear come to disability, they also experience poverty. The fact that three of the four disabled characters are noble, and the fourth, the Fool, occupies a privileged position in the court, makes the concurrence of their disability and poverty all the more conspicuous. ${ }^{21}$ Further, the embodied knowledge gained by the disabled characters in King Lear focuses pointedly on pity and poverty. ${ }^{22}$ Whenever characters speak to their understanding of disability, they testify to the debility Puar argues defines precarious populations. Both Lear's claim that 'pomp' must 
'shake the superflux' and Gloucester's call that 'distribution should undo excess' are rooted in the embodied knowledge of disability. The Fool in particular knows how disability gives rise to poverty. Weary from the beginning with the weight of survival, the Fool constantly cautions Lear about disregarding the tremendous difficulty of simply staying alive.

King Lear also widens the category of disability by repeatedly demonstrating the way in which indiscriminate violence masks itself as justice, particularly for the precarious population of the disabled/poor. John D. Staines argues that King Lear critiques early modern attempts to ascribe meaning to state violence, exposing its viciousness as 'nothing more than the arbitrary and unrestrained exercise of power'. In the blinding of Gloucester especially, King Lear forces spectators to 'see and feel vengeance for what it is, cruelty masquerading as a ritual display of justice. ${ }^{23}$ Given how often violence leads to disability and/or impoverishment in the play, I read King Lear as piercing the myth of the 'un/deserving poor' specifically. The stage tradition of counterfeit disability both interrogated and reinforced the early modern systems of justice that sought to label and control disability. By repeatedly showing the profound need experienced by all of its disabled characters and by exposing 'justice' as authorized violence, King Lear rewrites the counterfeit-disability trope to imagine a new vision of disability that demands a withholding of judgement and requires an extension of charity.

King Lear finally demonstrates its inclusion of precarious populations in disability by granting Edgar disabled knowledge even though his disability is false. In fact, Edgar's disability is extravagantly false. 'Bedlam beggars' were notoriously counterfeits, and the Poor Tom persona in particular had a reputation for theatrical fraudulence. ${ }^{24}$ And yet Edgar comes to 'feel what wretches feel' all the same, not because of the specific condition of his body, but because of his embodied knowledge. He knows the cramp of the cold, the pain of shredded, chapped skin, the ache of starvation, the frenzy of trying to manage new wounds, and the exhaustion of having to deal with old ones. Edgar — and King Lear — carries the embodied knowledge that traumatic events are often eclipsed by the endless expanse of their aftermath. ${ }^{25}$ While nearly every other play in the counterfeitdisability tradition is fixated on differentiating the fraudulently disabled from their genuinely disabled counterparts, King Lear is invested in including Edgar in the ranks of the deserving poor, because the play insists that everyone with knowledge of 'what wretches feel' deserves care.

In understanding disability as a body of knowledge, rather than a type of singular body, King Lear revises the category of disability, but this revision is not without limits. Jonathan Dollimore famously argues that King Lear stages 
useless empathy because its pity is only accessible via suffering, leaving the privileged insulated from understanding by their power and the poor never to be relieved of their pain. ${ }^{26}$ It would be easy to transpose Dollimore's thesis virtually unchanged to a reading of disability: disabled knowledge results from experiencing the position and precarity of disability so able-bodied people will continue in their privilege-protected ignorance and disabled people will remain unaided. While I am not willing accept that transposition as my thesis, I do acknowledge that King Lear refuses to treat the acquisition of disabled knowledge as a cure-all. Embodied knowledge of disability widens the scope of Gloucester's empathy and prompts him to give material provision to Poor Tom, but it does not spare him from despair, nor does it reunite him with his son, nor does it save his life. The embodied knowledge that Lear acquires not only fails to sustain him through the onslaughts at the end of the play but also does not seem to endure. Although he gains greater understanding of others' subjectivity and abjection through his own bodily knowledge of disability, that knowledge does not fully erase his past actions or his current self-importance. ${ }^{27}$ Edgar similarly cannot make effective use of his embodied knowledge, particularly after he steps out of the precarious social position he occupied as Tom o' Bedlam and returns to his economic and patrilineal privilege. It seems no accident that, almost instantaneously upon reclaiming his original identity, Edgar also returns to empty moralizing about disability. Speaking of his father, he tells his illegitimate brother Edmund, 'The dark and vicious place where thee he got / Cost him his eyes' (5.3.170-1), in direct contrast to Edgar's previous awareness that pain and misfortune are not moral qualities. Disabled knowledge might be faulty, fleeting, fractured. But when is knowledge ever absolute? One of the lessons of disabled knowledge and of King Lear is that all knowledge eventually flickers out.

But its multilayered, multivocal disability, defined not by bodily authenticity but by bodily knowledge, allows King Lear to extend that knowledge to the play's audiences and to prevent the play from becoming a full celebration of futility. Theatre-going, especially in early modern England, constituted a type of 'knowing-in-relation'. King Lear models an expansive version of 'thinking through disabled sensations and situations' not only for its characters but also for its audience, whom the play immerses in disabled sensations and situations. ${ }^{28}$ It does not promise anything. Playgoers may or may not partner with the play in the process of 'thinking through' disability, and whatever 'thinking through' they do may be limited, temporary, disorienting, or flawed, like that of the play's characters. To speak only for myself, the embodied knowledge of disability in King Lear has resounded with my own embodied knowledge of disability; my 
knowing-in-relation with the play has been affirming, revelatory, deeply disorienting, and even destructive - sometimes all at once. While disabled knowledge in the play does not save its characters from 'the promised end', that knowledge may have something to offer its audiences all the same: the clasp of a familiar hand in yours, the crack of your teeth against each other during an unexpected blow, the wash of rain on your face. 


\section{Notes}

1 For more on the institutionalization of early modern social policy and the articulation of the 'deserving' vs. 'undeserving' poor in discussions of charity, see Steve Hindle, The State and Social Change in Early Modern England, c. 1550-1640 (New York, 2000), https://doi.org/10.1057/9780230288461, and Thomas Max Safley, 'Introduction', in The Reformation of Charity: The Secular and the Religious in Early Modern Poor Relief, ed. Thomas Max Safley (Boston, 2003). For a survey of the effect of these policies on disabled people and understandings of disability, see Lindsey Row-Heyveld, “'The Lying'st Knave in Christendom”: Vagrancy, Charity, and Disability in the False Miracle of St. Alban's', Disability Studies Quarterly 29.4 (2009), n.p., https://doi.org/10.18061/dsq.v29i4.994.

2 For a discussion of the social and economic contexts of early modern English disability and an extended analysis of the counterfeit-disability stage tradition, see Lindsey Row-Heyveld, Dissembling Disability in Early Modern English Drama (New York, 2018), https://doi.org/10.1007/978-3-319-92135-8.

3 This is not to say that suffering has nothing to do with the process of knowing in the play. For a thoughtful reading of suffering and knowledge in King Lear, see David K. Anderson, Martyrs and Players in Early Modern England: Tragedy, Religion, and Violence on Stage (London: 2016), https://doi.org/10.4324/9781315594064.

4 Quotations reference William Shakespeare, King Lear, Arden Third Series, ed. R.A. Foakes (London, 1997), https://doi.org/10.5040/9781408160268.00000006.

5 Tobin Siebers, 'Shakespeare Differently Disabled', in The Oxford Handbook of Shakespeare and Embodiment: Gender, Sexuality, and Race, ed. Valerie Traub (Oxford, 2016), 441, https://doi.org/10.1093/oxfordhb/9780199663408.013.25.

6 Ibid., 443.

7 Merri Lisa Johnson and Robert McRuer, 'Cripistemologies: Introduction', Journal of Literary \& Cultural Disability Studies 8.2 (2014), 134, https://doi.org/10.3828/ jlcds.2014.12.

8 Siebers, 'Shakespeare', 438.

9 For a fuller analysis of the Fool in the context of early modern disability, see Alice Equestri, “This cold night will turn us all to fools and madmen”: Feste, Lear's Fool and the Border Between "Idiocy” and Mental Illness', Cahiers Élisabéthians 98 (2019), 1-10, https://doi.org/10.1177/0184767819835561.

10 Susan Wendell, 'Toward a Feminist Theory of Disability', Hypatia 4.2 (1989), 104, https://doi.org/10.1111/j.1527-2001.1989.tb00576.x.

11 Johnson and McRuer, 'Cripistemologies', 129. 
12 This pattern is more prominent in the folio text.

13 Anderson, Martyrs and Players, 107.

14 This is particularly true of the quarto text.

15 Johnson and McRuer, 'Cripistemologies', 130.

16 Robert McRuer and Merri Lisa Johnson, 'Proliferating Cripistemologies: A Virtual Roundtable', Journal of Literary \& Cultural Disability Studies 8.2 (2014), 157, https://doi.org/10.3828/jlcds.2014.13.

17 Critics have argued over how politically and economically radical these statements by Lear and Gloucester really are. For a survey, see Judy Kronenfeld, "'So distribution should undo excess, and each man have enough": Shakespeare's King Lear - Anabaptist Egalitarianism, Anglican Charity, Both, Neither?', ELH 59.4 (1992), 755-84, https://doi.org/10.2307/2873293. I concur with Chris Fitter that, read in the context of flawed early modern poor relief, these realizations by Lear and Gloucester 'excoriat[e] the meanness and hypocrisy constraining Poor Law assistance' and 'anatomiz[e] the hard heart of early modern England in solidarity with the subjected and disenfranchised'; Chris Fitter, "'As Full of Grief as Age": Protesting against the Poor Law in King Lear,' in Shakespeare and the Politics of Commoners: Digesting the New Social History, ed. Chris Fitter (Oxford, 2017), 233, https://doi.org/10.1093/oso/9780198806899.003.0010.

18 Johnson and McRuer, 'Cripistemologies', 141; italics in the original.

19 Jasbir A. Puar, 'The Cost of Getting Better: Suicide, Sensation, Switchpoints', GLQ: A Journal of Lesbian and Gay Studies 18.1 (2012), 154, $\underline{\mathrm{h}}$ ttps://doi.org/10.1215/10642684-1422179.

20 Jasbir A. Puar, The Right to Maim: Debility, Capacity, Disability (Durham, 2017), xvi-xvii, https://doi.org/10.1215/9780822372530.

21 Fitter identifies Shakespeare as arguing that poverty can lead to distraction in both 2 Henry IV and especially King Lear; 'As Full of Grief', 232.

22 Especially when discussing disability, we must remember that early modern understandings of pity and charity did not necessarily convey the condescension, inaction, and implicit class bias they have come to possess today. For more, see Danielle A. St Hilaire, 'Pity and the Failures of Justice in Shakespeare's King Lear', Modern Philology 113.4 (2016), 482-505, https://doi.org/10.1086/685381.

23 John D. Staines, 'Radical Pity: Responding to Spectacles of Violence in King Lear', in Staging Pain, 1580-1800: Violence and Trauma in British Theater, ed. Robert James Allard and Mathew R. Martin (Burlington, 2009), 85, https://doi.org/10.4324/9781315242491. St. Hilaire also effectively argues for the play's interrogation of the 'arbitrary nature of justice', 'Pity', 485. 
24 See William C. Carroll, “'The Base Shall Top Th’ Legitimate”: The Bedlam Beggar and the Role of Edgar in King Lear', Shakespeare Quarterly 38.4 (1987), 434, https://doi.org/10.2307/2870423.

25 For more on temporality and trauma in King Lear, see Patricia Cahill, 'Falling into Extremity' in Knowing Shakespeare: Senses, Embodiment, and Cognition, ed. Lowell Gallagher and Shankar Raman (London, 2010), 82-101, https://doi.org/10.1057/9780230299092 5.

26 Jonathon Dollimore, Radical Tragedy: Religion, Ideology and Power in the Drama of Shakespeare and His Contemporaries (Chicago, 1984), 191.

27 In addition to identifying the way Lear reverts back to his previous understandings of power and hierarchy at the end of the play, St. Hilaire points out the limits to the seemingly socially radical statements offered earlier by Lear and Gloucester, arguing that their pity is not exclusively for the poor but also for themselves; 'Pity', 494.

28 Among many others, Erika T. Lin effectively explores the material dimensions of 'knowing-in-relation' for early modern theatregoers in Shakespeare and the Materiality of Performance (New York, 2012), https://doi.org/10.1057/9781137006509. Heather James discusses how early modern tragedy created sympathetic identification with playgoers in order to revise social hierarchies in just the way I believe is happening in King Lear; see 'Dido's Ear: Tragedy and the Politics of Response', Shakespeare Quarterly 52.3 (2001), 360-82, https://doi.org/10.1353/shq.2001.0044. 